Revista de Estudios Histórico-Jurídicos

[Sección Historia del Derecho Canónico]

XXXIII (Valparaíso, Chile, 2011)

[pp. 613 - 637]

\title{
El llamado "III Concilio Provincial Mexicano" y los "Estatutos de la Santa Iglesia de México" o "Reglas CONSUEtas de la CATEdRal de MÉXico"*
}

["The so-Called 'III Mexican Provincial Council' and the 'Statutes of the Holy Church of Mexico' or the 'Customary Rules of Mexico's Cathedral'”]

\author{
Sebastián Terráneo \\ Pontificia Universidad Católica Argentina
}

\begin{abstract}
RESUMEN
Los estudios sobre el III Concilio Provincial de México (1585) cuyo impulso se ha renovado con la edición de sus manuscritos en la primera década de este siglo no han considerado uno de sus documentos, Los Estatutos de la Santa Iglesia de México, fruto de esta Asamblea que, como sus decretos, recibió la doble aprobación pontificia (1589) y real (1591). El presente artículo aborda estos Estatutos que no son sino la regla consueta del III Concilio de México, es decir, la normativa reguladora de los diversos aspectos cultuales de las catedrales y de los derechos y obligaciones del Cabildo eclesiástico. En este artículo se estudian las fuentes, estructura y contenido de la consueta mexicana para finalizar considerando la importancia de este tipo de normativa en el concierto de las fuentes del Derecho Canónico Indiano.

Palabras clave

Derecho Canónico Indiano - III Concilio Provincial de México - Reglas Consuetas - Fuentes del Derecho Canónico Indiano.
\end{abstract}

\begin{abstract}
The studies about the Concilium Mexicanum Provinciale III (1585), momentum of which has been renovated with the publishing of its manuscripts in the first decade of this century, have not considered one of its documents, The Statutes of the Holy Church of Mexico, which resulted from this Meeting, as well as its decrees, received both the Pontifical (1589) and the Royal approval. This article addresses these Statutes that are nothing but the customary rule of the Concilium Mexicanum Provinciale III, that is, the regulatory laws on the different cultural aspects of the cathedrals and about the rights and obligations of the Ecclesiastical Council. This article studies the sources, structure and content of the Mexican customary rules, and finally it considers the importance of this kind of regulations in the fabric of sources in the Canon law of the Indies.

\section{KeYwords}

Canon Law of the Indies - Concilium Mexicanum Provinciale III - Customary Rules - Sources of the Canon Law of the Indies.
\end{abstract}

RECIBIDO 3 de marzo y ACEPTADO el 11 de abril de de 2011

* Profesor en la Facultad de Derecho Canónico de la Pontificia Universidad Católica Argentina. Dirección postal: Calle $22 \mathrm{~N}^{\circ}$ 745, 6600 Mercedes (B), Argentina. Correo electrónico: terraneos@yahoo.com.ar 


\section{INTRODUCCIÓN}

El III Concilio Provincial Mexicano (1585) ha sido ampliamente estudiado ${ }^{1}$,

${ }^{1}$ La bibliografía sobre el III Concilio de México es abundantísima. Entre las más importantes se pueden señalar: Arriaga, Benito Notas, en Galván Rivera, Mariano (editor), Concilio III Provincial Mexicano (México, Eugenio Mailleferte y Compañía, 1859); Burrus, Ernest, The Autor of the Mexican Council's Catechisms, en The Americas, 15 (Washington, 1958), pp. 171182, Salazar's report to the Third Mexican Council, en The Americas, 17 (Washington, 1960), pp. 65-64; CarRILlo CázARes, Alberto (editor), Manuscritos del concilio tercero provincial mexicano (1585). Edición, estudio introductorio, notas, versión paleográfica y traducción de textos latinos (Zamora, El Colegio de Michoacán - Universidad Pontificia de México, 2006-2010); Durán, Juan Guillermo, La transmisión de la fe. Misión apostólica, catequesis y catecismos en el Nuevo Mundo (siglo XVI), en Escudero ImBERT, José (editor), Historia de la Evangelización de América. Trayectoria, identidad y esperanza de un continente. Actas del Simposio Internacional (Ciudad del Vaticano, Librería Editrice Vaticana, 1992), pp. 323-352, Monumenta Catechetica hispanoamericana. (Siglos XVI-XVIII), III (pro manuscrito); GalVÁn RIVERA, Mariano (editor), Concilio III Provincial de México, cit.; LoRENZANa, Francisco, Apéndice a los Concilios mexicanos primero y segundo, publicados por Nicolás de León. Bibliografía mexicana siglo XVIII (México, Imprenta del Superior Gobierno 1907); FoRnes AzCoITI, Ignacio, El proceso de la aprobación romana del III Concilio de México (1585-1589), Tesis doctoral (Roma, Pontificia Universidad de la Santa Cruz, 2005); Galindo Bustos, Jesús, Estudio del aparato de fuentes del Tercer Concilio Mexicano. Tesis doctoral (Roma, Pontificia Universidad de la Santa Cruz, 2004); García Prieto, Zenón, Los tres primeros concilios de México, en Revista Española de Derecho Canónico, 46 (Salamanca, 1989) pp. 435-484; LlaGuno, José, La personalidad jurídica del indio y el III concilio provincial mexicano (1585) (México, Porrúa, 1963); Lopetegui, León - Zubillaga, Félix, Historia de la Iglesia en la América Española. Desde el Descubrimiento hasta comienzos del siglo XIX. México. América Central. Antillas (Madrid, BAC, 1965), pp. 564-613; LundBerg, Magnus, Las Actas de los tres primeros concilios mexicanos. Historia diplomática y estudio de su itinerario, en Anuario de Historia de la Iglesia, 15 (Pamplona, 2006), pp. 259-268; LuQUE AlCAIDE, Elisa, El memorial inédito de Jerónimo Mendieta al III Concilio provincial de México (1585) Estudio preliminar y trascripción, en Anuario de Historia de la Iglesia, 1 (Pamplona, 1992), pp. 305-324, Experiencias evangelizadoras granadinas en el III Concilio Mexicano, en AA.Vv El reino de Granada y el Nuevo Mundo ( $V$ Congreso internacional de Historia de América) (Granada, Diputación Provincial de Granada, 1994), I, pp. 607-617; MarTínez FerRer, Luis, El sacramento de la confesión en el Directorio para confesores y penitentes del Tercer Concilio Mexicano (1585). Tesis doctoral, en Anuario de Historia de la Iglesia, 5 (Pamplona, 1996), pp. 519-526; El MIsmo, Directorio para confesores y penitentes. La pastoral de la confesión en el Tercer Concilio Mexicano (1585) (Pamplona, Eunate, 1996); EL MISMO, Fuentes e historiografia del III Concilio Mexicano (1585), en Saranyana, Josep-Ignasi y otros (editores), Actas del XVI Simposio Internacional de Teología de la Universidad de Navarra (Pamplona, Eunsa 1996), pp. 355-366; El MISMO, La penitencia en la primera evangelización de México (1523-1585) (México, Universidad Pontificia de México, 1998, Otras recepciones de Trento en América (1585-1628), en Saranyana, Josep-Ignasi (editor), Teología en América Latina. Desde los orígenes a la Guerra de Sucesión (1493-1715) (Madrid, Iberoamerica, 1999), I, pp. 180-219; El mismo, Decretos del Concilio tercero provincial mexicano (1585), edición histórico crítica y estudio preliminar (Zamora, El Colegio de Michoacán - Universidad Pontificia de la Santa Cruz 2009-2010); OrTiz TreviÑo, Rigoberto, El tercer concilio provincial mexicano, o como los obispo evadieron al real patronato indiano, en Anuario Mexicano de Historia del Derecho, XV (México, 2003), pp. 77-94; Pérez PuenTe, Leticia, Dos proyectos postergados. El Tercer Concilio Provincial Mexicano y la secularización parroquial, en Estudios de Historia Novohispanos, 35 (México JulioDiciembre, 2006), pp. 17-45; Poole, Richard, Pedro Moya de Contreras. Catholic reform and Royal Power in New Spain 1571-1591 (Berkeley - Los Angeles, University of California Press, 
estudio que se ha renovado y profundizado a partir de la reciente edición de sus manuscritos. Así, esta Asamblea ha sido abordada en sus más diversos aspectos estudiando los investigadores las circunstancias de su celebración, los memoriales presentados ante el mismo, las características de sus decretos y sus fuentes. Objeto de particular atención, también, han sido sus instrumentos pastorales muchas veces enfocados desde un punto de vista teológico aunque presentan, asimismo, interesantes matices canónicos. Sin embargo, de la masa documental que implica todo lo relativo a la celebración de este Concilio no ha llamado la atención de los expertos un documento que como el resto de su cuerpo normativo también fue objeto de la doble aprobación pontificia (1589) y real (1591). Me refiero a los Estatutos de la Iglesia de México sancionados por este Concilio provincial ${ }^{2}$.

\section{LAS CONSUETAS ${ }^{3}$}

Los Estatutos de la Santa Iglesia de México no son sino consuetas, es decir, un cuerpo normativo que regulaba el Capítulo o Cabildo eclesiástico sus cargos, funciones y retribuciones de quienes lo integraban además de organizar las actividades de coro, altar y las procesiones ${ }^{4}$.

1987); Saranyana, Josep-Ignasi, Sobre los orígenes del cristianismo en América. Historia doctrinal de una polémica, en Anuario de Historia de la Iglesia, 1 (Pamplona, 1992), pp. 275-285; SARANyana, , Josep-Ignasi - Alejos-Grau, Carmen, La Primera Recepción de Trento en América (15651582) en Saranyana, Josep-Ignasi (editor), Teología en América Latina, cit. (1), I, pp. 131-148; Saranyana, Josep-Ignasi - LuQue AlCalde, Elisa, Fuentes manuscritas inéditas del III Concilio Mexicano (1585), en Annuarium Historie Conciliorum, 22 (Paderborn, 1990), pp. 273-290, Los instrumentos pastorales del III Concilio Mexicano (1585), en Scripta Theologica, 23 (Roma, 1991), pp. 185-196; TERRÁNEO, Sebastián, La recepción de la tradición conciliar limense en los Decretos del III Concilio Provincial Mexicano. Tesis doctoral (Buenos Aires, Pontificia Universidad Católica Argentina, 2010); Zubillaga, Félix, Tercer Concilio Mexicano, 1585: Los memoriales de Juan de la Plaza, S.J., en Archivum Historicum Societatis Jesu, 30 (Roma, 1961), pp. 180-244.

${ }^{2}$ Estatutos ordenados por el Santo Concilio III Provincial Mexicano en el año del Señor MDLXXXV según el mandato del Sacrosanto Concilio Tridentino, decretado en la sesión XII, cap. 24 de la Reformación, en la palabra Cetera, en GaLván Rivera, Mariano (editor), cit. (n. 1), pp. 448-563 [en adelante: Estatutos].

${ }^{3}$ Oviedo Cavada, Carlos, Las consuetas de las catedrales de Chile, 1689 y 1744, en Revista Chilena de Historia del Derecho, 12 (Santiago de Chile, 1986), pp. 129-154; Dougnac RodríGUEZ, Antonio, Manual de Historia del Derecho Indiano (México, Instituto de Investigaciones Jurídicas, 1994), p. 312; Barrientos Grandon, Javier, Historia del Derecho indiano (Roma, Il Cigno Galileo Galilei, 2000), pp. 388-390; GRIGNANI, Mario, La regla consueta de santo Toribio de Mogrovejo y la primera organización de la Iglesia americana (Santiago de Chile, Ediciones Universidad Católica de Chile, 2009), pp. 123-127; Martínez de SÁnCHEZ, Ana María, Las consuetas de las catedrales de Santiago del Estero y Córdoba en los siglos XVII y XVIII, en GONZÁLEZ VALE, Luis (coordinador), Actas y Estudios del XIII Congreso del Instituto Internacional de Historia del Derecho Indiano (San Juan de Puerto Rico, Historiador Oficial de Puerto Rico-Asamblea Legislativa de Puerto Rico, 2003), II, pp. 41-68; El MISMO, Las consuetas del obispado de Tucumán, en Revista de Estudios Históricos-Jurídicos, 28 (Valparaíso, 2006), pp. 491-511, Fuentes de archivo para el estudio del Derecho canónico indiano local, en Revista de Estudios Históricos-Jurídicos, 30 (Valparaíso, 2008), 492-494.

${ }^{4}$ Martínez de SÁnchez, Ana María, Las consuetas del obispado de Tucumán, cit. (n. 3), pp. 493-494. 
Se entiende por "consueta" ya sea a todo el cuerpo normativo como cada una de las prescripciones que lo constituían ${ }^{5}$. Este tipo de norma técnicamente ha de incluirse en el Derecho consuetudinario ${ }^{6}$. Su propia denominación de "consueta" surge de su vinculación con la costumbre. Los usos y costumbres constituyen un fundamento importante de esta legislación, los mismos estando vigentes al tiempo de la redacción de la norma influían decididamente en el texto aprobado dado que aunque no existieran estatutos escritos las catedrales gozaban de una organización propia que derivaba de la Erección y de la práctica diaria ${ }^{7}$. Hubo, luego, reglas consuetas que se cristalizaron en la escritura y otras sólo conocidas por tradición oral ${ }^{8}$.

Estas normas consuetudinarias, a parte de establecer los derechos y obligaciones del Cabildo eclesiástico incluyen distintas dimensiones rituales de las ceremonias religiosas como el orden en tocar las campanas, normas sobre la celebración de la Misa y sobre la asistencia a los Oficios Divinos. Regulan, asimismo, distintos aspectos en el orden de la predicación, lo referente al maestro de ceremonias, el apuntador, etc. En caso de violación a la norma establecida en la consueta se solía prever la privación de algunos días de los frutos a los que tenía derecho el prebendado u otras penas pecuniarias?

La normativa analizada por lo general es coincidente en las distintas catedrales, al menos, en sus contenidos esenciales en los que era prácticamente imposible innovar. La novedad podía encontrarse en elementos accidentales vinculados al símbolo y la representación ${ }^{10}$.

La autoría de los textos debe atribuirse a los respectivos obispos que lo hacían, usualmente, luego de un instancia sinodal aunque no siempre se haya verificado este extremo como ocurre en el caso de la regla consueta del III Concilio mexicano cuya autoría formal ha de referir a la misma Asamblea. Por tanto, la norma podía ser un texto unitario que se daba a conocer junto al respectivo sínodo o bien independientemente de él ${ }^{11}$. Al menos, para lo que se refiere a las consuetas de la diócesis de Tucumán algunas de ellas fueron simplemente disciplinares a diferencia de otras más preocupadas por lo ritual reiterándose alguna temática a lo largo de los siglos XVII y XVIII incluso alguna adoptando una cariz regalista respondiendo al sentir y pensar de cada obispo de acuerdo a la circunstancia que le haya tocado gobernar ${ }^{12}$.

En la medida en que el proceso evangelizador imponía el surgimiento de las

${ }^{5}$ Oviedo Cavada, Carlos cit. (n. 3), p. 129.

${ }^{6}$ Tau Anzó́tegui, Víctor, El poder de la costumbre. Estudios sobre el Derecho Consuetudinario en América hispana hasta la emancipación (Instituto de Investigaciones de Historia del Derecho, Buenos Aires, 2001), pág. 123.

${ }^{7}$ Oviedo Cavada, Carlos, cit. (n. 3), p. 131.

${ }^{8}$ Martínez de Sánchez, Ana María, Las consuetas del obispado de Tucumán, cit. (n. 3), p. 493.

${ }^{9}$ Martínez de Sánchez, Ana María, Fuentes, cit. (n. 3), p. 494.

${ }^{10}$ Martínez de Sánchez, Ana María, Fuentes, cit. (n. 3), p. 492.

${ }^{11}$ Martínez de SÁnchez, Ana María, Fuentes, cit. (n. 3), p.493.

${ }^{12}$ Martínez de Sánchez, Ana María, Las consuetas del obispado de Tucumán, cit. (n. 3), p. 494. 
distintas catedrales americanas estas, a su vez, se van proveyendo de sus propias reglas consuetas. Así, los obispados de México, Lima, Tucumán las distintas diócesis de Chile, etc. Las primeras consuetas indianas, como la mexicana aquí estudiada, se inspiraron en las ordenanzas respectivas de la arquidiócesis de Sevilla conocida como "Regla vieja" la cual también constituye una fuente expresamente mencionada en los Estatutos mexicanos.

\section{FUENTES}

Las consuetas del Concilio Mexicano de 1585 llevan por nombre: Estatutos ordenados por el Santo Concilio III Provincial Mexicano en el año del Señor MDLXXXV según el mandato del Sacrosanto Concilio Tridentino, decretado en la sesión XII, capitulo 24 de la Reformación, en la palabra Cetera; y en las palabras iniciales del mismo cita como fundamento de la aplicación de éste en todas iglesias catedrales de la provincia y del arzobispado el mismo Decreto tridentino ${ }^{13}$.

En efecto el Concilio de Trento en la sesión XXIV, capítulo $12^{\circ}$ : De reforma, manda a hacer las reglas consuetas.

En la mayoría de los Decretos del Concilio de México de 1585, al pie de ellos, se ha indicado la fuente que, en principio, ha sido inspiradora en la redacción de la norma. Por otra parte, no siempre la fuentes indicadas son tales, ya que, a veces corresponden a obras posteriores al Concilio. Esto se debe a que el aparato de fuentes se ha agregado a las actas en un tiempo cercano a su publicación en $1622^{14}$.

Una parte importante de estas fuentes, al parecer, han sido tomadas de los mismos Apuntamientos para Decretar, es decir, los esquemas o borradores de los futuros Decretos del III Concilio Mexicano que obran entre los manuscritos que se han conservado de esa Asamblea, y otras han sido agregadas al realizar el trabajo de edición, en principio, atribuible a Juan de Salcedo autor material de los Decretos ${ }^{15}$.

Por los que respecta a los Estatutos de la Santa Iglesia de México se puede decir que, según su aparato de fuentes, las principales normas en que se ha inspirado son las consuetas de las Iglesia sevillana o hispalense con veinticuatro citas seguida de los estatutos de la Iglesia compostelana con la remisión a veintidós de sus constituciones. Otra consueta importante en la elaboración de la norma mexicana ha sido la de Granada con quince remisiones. Como fuente también se ha recurrido a los diversos Concilios que se ocupan de este tema así, por supuesto, el de Trento (12). Se recurre también a los Concilios milaneses así el Primero de 1565 (2), el Segundo de 1569 (2), el Tercero de 1573 (6), el Cuarto de 1576 (3) y el Quinto de 1579 (1). Otros Concilios europeos citados son el Compostelano de 1565 - 1566 (2) y el Toletano de 1582 - 1583 (1). Interesantes son las remisiones al II Concilio Provincial de Lima de 1567 - 1568 al que se recurre en dos

${ }^{13}$ Estatutos, cit. (n. 2), pp. 450-451.

${ }^{14}$ Galindo Bustos, Jesús, cit. (n. 1), p. 229.

${ }^{15}$ Galindo Bustos, Jesús, cit. (n. 1), pág. 229. Ver también, Martínez Ferrer, Luis, Decretos, cit. (n. 1), pp. 139-148. 
oportunidades. Se cita, asimismo, un motu propio de Pío IV y el motu propio de Pío V sobre la profesión de fe.

Se recurre a seis autores para fundar normas: San Agustín, santo Tomás de Aquino, Juan Trullo, Diego de Covarrubias, el Navarro y también a una obra del cardenal Antonio Carrafa.

\section{ESTRUCTURA Y CONTENIDO}

Los Estatutos se pueden dividir en cuatro partes. Se inician con un Proemio o introducción ${ }^{16}$ para pasar luego al acta de Erección de la Iglesia de México, la que es igual a las demás de la misma provincia ${ }^{17}$ cuya autoría corresponde al obispo Juan de Zumárraga ${ }^{18}$ dada en Toledo en 25 de diciembre de 1534 . Más precisamente se trata del Decreto episcopal de ejecución de la bula de erección de la diócesis que, ordinariamente, era el germen de las consuetas ${ }^{19}$ y constituye una de sus fuentes más directas ${ }^{20}$. La bula de creación de la diócesis debía ser ejecutada por el propio Prelado estableciendo en la realidad concreta todo aquello que en abstracto disponía el acto pontificio permitiendo de esta manera el inicio organizado de la nueva Iglesia particular. Esto tenía como punto de partida la erección de la iglesia catedral, por ello, esta ejecución de la bula papal es, generalmente, llamada como erección de la catedral ${ }^{21}$. Luego, siguen, la parte más importante de este documento, los Estatutos $^{22}$ propiamente dichos divididos a su vez, en cuatro partes y, finalmente, el Orden que se ha de observar en el coro ${ }^{23}$ establecido por el arzobispo de México Alfonso de Montufar en su sede episcopal el día 16 de enero de 1570.

\section{El Decreto de erección.}

El acta de erección de la Iglesia de México luego de transcribir la bula del papa Clemente VII del 2 de septiembre de 1530 en la que erige la diócesis de México ${ }^{24}$ determina, como por otra parte lo indica el mismo documento pontificio y como se solía hacer en este tipo de documentos ${ }^{25}$, la nómina detallada de los cargos que constituirían la nueva Iglesia cuales serían y demás circunstancias.

${ }^{16}$ Estatutos, cit. (n. 2), pp. 449 - 451.

${ }^{17}$ Estatutos, cit. (n. 2), pp. 452-479.

${ }^{18}$ Estatutos, cit. (n. 2), p. 452.

${ }^{19}$ Oviedo Cavada, Carlos, cit. (n. 3), p. 136; Martínez de Sánchez, Ana María, Las consuetas de las catedrales de Santiago del Estero y Córdoba, cit. (n. 3), p. 42.

${ }^{20}$ Oviedo Cavada, Carlos, cit. (n. 3), p.131.

${ }^{21}$ Oviedo Cavada, Carlos, cit. (n. 3), p.134.

${ }^{22}$ Estatutos, cit. (n. 2), pp. 479-548.

${ }^{23}$ Estatutos, cit. (n. 2), pp. 549-563.

${ }^{24}$ Estatutos, cit. (n. 2), pp. 457.

${ }^{25}$ Martínez de SÁncheZ, Ana María, Las consuetas del obispado de Tucumán, cit. (n. 3), p. 498. 
Se instituyen cinco dignidades: el deán ${ }^{26}$, el $\operatorname{arcediano}^{27}$, el chantre o cantor ${ }^{28}$, el maestreescuela o escolar ${ }^{29}$ que a diferencia de lo establecido en otros decretos de erección americanos ${ }^{30}$ en México no se exigía que esta dignidad sea ocupada por un graduado de una universidad española, y, finalmente, el tesorero ${ }^{31}$. Se establecen, asimismo, diez canonicatos y prebendas las cuales se separan de las dignidades mencionadas y se manda que nunca puedan obtenerse juntamente con alguna otra dignidad. Estos canonicatos y prebendas sólo pueden ser otorgadas a quienes sean presbíteros ${ }^{32}$. Se instituyen además seis raciones íntegras las cuales corresponden a quienes han recibido el diaconado y, por otra parte, seis medias raciones que corresponden a quienes fueron promovidos al subdiaconado ${ }^{33}$.

Una norma que no siempre se encuentra en otras reglas consuetas ${ }^{34}$ es la que

26 "El deanato, que será en la misma iglesia la primera dignidad después de la pontifical, el cual cuide y provea que el oficio divino, y todas las otras cosas que pertenecen al culto de Dios, tanto en el coro como en el altar, y en las procesiones en la iglesia, y fuera de ella, en cap. de convento, de iglesia ó de cabildo, donde quiera que se congreguen para rezarlo, se hagan muy bien y rectamente, con aquel silencio, modestia y honestidad que corresponde; al cual también pertenecerá conceder licencia á aquello á quienes conviene salir del coro por motivo que tengan, expresada causa, y no de otro modo" (Estatutos, Erección de la Iglesia de México, la que es igual a las demás de la misma provincia, \$ I).

27 "El arcedianato de la misma ciudad, al cual corresponde el examen de los clérigos ordenandos, celebrando el prelado solemnemente: le pertenecerá ejercer la administración de la ciudad y de la diócesis, si por el prelado se le encargare la visita, y las otras cosas que de derecho común le competen; y el que obtenga esta dignidad debe por lo menos tener el grado de bachiller en derecho, ya sea canónico ó civil, ó en teología, por alguna universidad" (Estatutos, cit. (n. 2), Erección de la Iglesia de México, la que es igual a las demás de la misma provincia, \$ II).

28 "La chantría, á la cual ninguno pueda se presentado si no fuere instruido y perito en la música, á lo menos en el canto llano, cuyo oficio será cantar en el facistol, y enseñar á cantar á los servidores de la iglesia, y ordenar, corregir y enmendar por sí, y no por otro, las cosas que pertenecen y miran al canto en el coro y donde quiera” (Estatutos, cit. (n. 2), Erección de la Iglesia de México, la que es igual a las demás de la misma provincia, \$ III).

29 "El maestrescolia, á la cual tampoco sea presentado alguno que no sea bachiller en alguno de los derechos, ó en artes, por alguna universidad general, el cual tendrá obligación de enseñar por sí, ó por otro, la gramática á los clérigos y á los servidores de la iglesia, y á todos los de la diócesis que quieran oír las lecciones" (Estatuto, Erección de la Iglesia de México, la que es igual a las demás de la misma provincia, $\$$ IV).

${ }^{30}$ Véase Decreto de ejecución de la erección del Obispado del Tucumán firmado por el Obispo Francisco de Vitoria en Sevilla: 18.XI. 1578, en AranCibia, José María-Dellaferrera, Nelson (editores), Los Sinodos del Antiguo Tucumán (Buenos Aires, Teología, 1979), n. 4.

31 "La tesorería, á la cual corresponderá hacer cerrar y abrir la iglesia, tocar las campanas, guardar todos los utensillos de la iglesia, lámparas y candiles, cuidar del incienso, de las luces, del pan y del vino, y de las demás cosas necesarias para celebrar, proveer de los réditos de la fábrica de la iglesia, manifestándolo al Cabildo, para que se haga con su acuerdo" (Estatutos, Erección de la Iglesia de México, la que es igual a las demás de la misma provincia, $\$ \mathrm{~V})$.

${ }^{32}$ Estatutos, Erección de la Iglesia de México, la que es igual a las demás de la misma provincia, $\$ \mathrm{VI}$.

${ }^{33}$ Estatutos, cit. (n. 2), Erección de la Iglesia de México, la que es igual a las demás de la misma provincia, $\$$ VII.

${ }^{34} \mathrm{Al}$ menos, no está presente en el Decreto de ejecución de la erección del Obispado del Tucumán, cit. (n. 30). En cambio, lo mismo que en México se dispone en el Decreto de erección de la Santa Iglesia Catedral de la Imperial véase DE AzúA E Iturgoyen, Pedro Felipe, Sínodo de 
establece que en ninguno de los oficios anteriormente mencionados como tampoco en otros beneficios de las diócesis mexicanas pueda ser presentado un candidato que con ocasión de alguna orden, privilegio u oficio este exento de la jurisdicción ordinaria del obispo de manera que presentado o instituido un exento tales actos por la fuerza misma del derecho se reputan nulos ${ }^{35}$. Es decir, se excluyen de tales cargos diocesanos a los miembros de las órdenes religiosas.

El obispo se reserva nombrar y remover rectores ${ }^{36}$ de acuerdo a la necesidad de la iglesia catedral ${ }^{37}$. Por otra parte, se establecen seis acólitos y otros tantos capellanes $^{38}$.

Las presentación de las dignidades, canonicatos, raciones y medias raciones como las que en el futuro se crearían se reserva a la Corona española ${ }^{39}$ mientras que corresponderá a la autoridad episcopal junto con el Cabildo la elección o provisión de estos "acólitos y capellanes" quienes no deben ser familiares de obispo alguno ni de algún miembro del Cabildo "ni lo hayan sido en el tiempo de la vacante" ${ }^{40}$.

Otros oficios que establece el Decreto de erección de la Iglesia mexicana son: el

Concepción (Chile) 1744 en Santiago-Otero, Horacio - García y García, Antonio (editores), Sinodos Americanos 3 (Madrid-Salamanca, Instituto "Francisco Suárez" del CSIC-Instituto de Historia de la Teología Española de la UPS, 1984), pp. 12-13, y también el de la Catedral del Cuzco por el cual también se regía la Catedral de Santiago de Chile véase Carrasco SaAvEdra, Bernardo-De Alday y Aspee, Manuel, Sinodos de Santiago de Chile de 1688 y 1763 en García y García, Antonio - Santiago-Otero, Horacio - (editores), Sinodos Americanos, 2 (MadridSalamanca, Instituto "Francisco Suárez" del CSIC-Instituto de Historia de la Teología Española de la UPS, 1983), pp. 298-299.

${ }^{35}$ Estatutos, cit. (n. 2), Erección de la Iglesia de México, la que es igual a las demás de la misma provincia, $\$$ VIII.

${ }^{36}$ Los manuscritos del III Concilio Provincial Mexicano recogen un litigio presentado ante la Asamblea vinculado a este tema. Véase CARRILlo Cázares, Alberto (editor), cit. (n. 1), I, pp. 820-838.

37 " [...] y estos ejerzan el oficio en dicha nuestra iglesia catedral recta y debidamente, celebrando misas, oyendo confesiones, y administrando cauta y solícitamente los demás Sacramentos"(Estatutos, Erección de la Iglesia de México, la que es igual a las demás de la misma provincia, $\$ I X)$.

38 "Y establecemos seis acólitos, los que ejercerán por orden cada día el oficio del acolitado en el ministerio del altar: ordenamos además que haya seis capellanes, cualquiera de los cuales estará obligado, tanto en las horas nocturnas como en las diurnas, y tambien para las misas, á asitir personalmente al facistol, y á celebrar en cada mes veinte misas, si no estuviere impedido por enfermedad ó por otro justo impedimento"(Estatutos, Erección de la Iglesia de México, la que es igual a las demás de la misma provincia, $\$ \mathrm{X})$. $\$ \mathrm{XI}$.

${ }^{39}$ Estatutos, Erección de la Iglesia de México, la que es igual a las demás de la misma provincia, $\S$ XII.

${ }^{40}$ Estatutos, Erección de la Iglesia de México, la que es igual a las demás de la misma provincia, 
sacristán $^{41}$, el organista ${ }^{42}$, el pertiguero ${ }^{43}$, el mayordomo ${ }^{44}$, el cancelario o notario de la iglesia y del Cabildo ${ }^{45}$ y el perrero ${ }^{46}$.

De los oficios enumerados hasta aquí se suspenden por el Decreto de erección: De las dignidades la de tesorero; cinco canonicatos y todas las raciones íntegras como medias. La razón: "no bastan al presente los frutos, réditos y productos de los diezmos" ${ }^{\prime 7}$. Todos quienes cubren estos oficios tienen la obligación de residir en la iglesia catedral por ocho meses continuos o interrumpidos de lo contrario previamente interpelados y no existiendo causa justa y racional se declarará vacante el oficio pudiéndose proceder a una nueva provisión. Por justa causa se entiende la enfermedad siempre que el enfermo permanezca en la ciudad o en los alrededores. Si la enfermedad sobreviene estando fuera de la ciudad se entiende que hay causa de justificación en la medida que el afectado regresaba o se disponía a regresar a la ciudad siempre que tales extremos estén suficientemente acreditados. Asimismo, se entiende que hay causa justa cuando la ausencia se debía al cumplimiento de un mandato del obispo o del Cabildo juntamente, por causa y utilidad de la Iglesia debiendo concurrir estos tres requisitos simultáneamente.

La norma divide en cuatro partes los frutos, réditos y productos de todos los

41 "El oficio de sacristán, el cual tendrá obligación de desempeñar aquellas cosas que corresponden al oficio de tesorero, presente él mismo y de comisión suya, y en su ausencia por disposición del Cabildo" (Estatutos, Erección de la Iglesia de México, la que es igual a las demás de la misma provincia, $\$$ XIII).

42 "El oficio de organista, el cual tendrá obligación de tocar los órganos en los dias festivos, y en otros tiempos por disposición del prelado ó del Cabildo". (Estatutos, Erección de la Iglesia de México, la que es igual a las demás de la misma provincia, $\$$ XIV).

43 "El oficio de pertiguero, cuya obligacion es ordenar las precesiones é ir ante el prelado, presbítero, diácono, subdiácono y demás ministros, cuando van del coro á la sacristía ó al altar, ó del altar á la sacristía ó al coro" (Estatutos, Erección de la Iglesia de México, la que es igual a las demás de la misma provincia, $\$ \mathrm{XV})$.

44 "El oficio de mayordomo, ó de procurador de la fábrica de la iglesia y hospital, el cual presidirá á los arquitectos, albañiles, carpinteros y otros oficiales que trabajen para edificar las iglesias, el cual también deberá cobrar por sí ó por otros los réditos y productos anuales, y cualesquiera emolumentos y obvenciones que de cualquier modo pertenezcan á dicha fábrica y hospital, y hacer los gastos; y ha de dar cuenta anualmente de lo recibido y gastado al obispo y Cabildo, ó á los oficiales nombrados por los mismos especialmente para esto; también se dispone, que su elección ó remoción sea á voluntad de ellos, y antes que se le admita á la administración de dará fianza idónea" (Estatutos, Erección de la Iglesia de México, la que es igual a las demás de la misma provincia, $\$ \mathrm{XVI})$.

45 “Además el oficio de cancelario ó notario de la iglesia y del Cabildo, el cual deba guardar en el protocolo, y anotarlos en sus apuntamientos, cualesquiera contratos entre la iglesia, el obispo y el Cabildo, y anotar y escribir las donaciones, posesiones, censos, feudos, precarios, donados ya, ó que hayan de donarse en lo sucesivo por los mismos obispos, por el Cabildo é iglesia, y guardar los instrumentos; distribuir tambien á los beneficiados las partes de los réditos, y recibir y pagar las raciones" (Estatutos, Erección de la Iglesia de México, la que es igual a las demás de la misma provincia, $\$$ XVII).

46 "El oficio de perrero, el cual eche de la iglesia á los perros, y limpiará la iglesia todos los sábados y en las vísperas de cualesquiera fiestas que tengan vigilias, y en otros días donde y cuando le fuere mandado por el tesorero" (Estatutos, Erección de la Iglesia de México, la que es igual a las demás de la misma provincia, $\$$ XVIII).

${ }^{47}$ Ibíd., \$ XIX. 
diezmos tanto de la catedral como de las demás iglesias. Una parte se asigna al obispo, otra al deán, al Cabildo y a los otros ministros de acuerdo a una distribución que regula el mismo Decreto. De estas partes el rey recibe las llamadas tercias de la cual liberó a la cuarta parte de los diezmos que le correspondían al obispo y al Cabildo. Las restantes dos cuartas partes se procedió a dividir en novenos de los cuales dos se aplican en favor del Rey "en señal de superioridad y del derecho de patronato $[\ldots]]^{\prime 48}$.

Una norma a destacar del Decreto estudiado es la prevista en el $₫$ XXVII en donde se manda que en todas las iglesias parroquiales, excluyendo la catedral, se creen tantos beneficios simples como puedan crearse de acuerdo con la cantidad de réditos aplicada a estos beneficiados según la previsión del mismo Decreto. No se determina un número cerrado de beneficios sino que en la medida que crezcan los frutos se debe aumentar el número de ministros de estas iglesias. Ahora bien, y esta es la parte por subrayar aquí, estos beneficios simples, contempla el Decreto, deben proveerse: "Solamente en hijos de padres descendientes de los habitantes que de España se trasladaron á dicha provincia, ó que en lo sucesivo pasaren á habitarla, hasta que en lo de adelante vista y conocida por nos ó nuestros sucesores la cristiandad y capacidad de los indios, á instancia y peticion del sobredicho patrono, ahora ó por tiempo existente, pareciere bien proveerse dichos beneficios en los indios naturales (previo el exámen y oposicion, segun la forma y laudable costumbre observada hasta ahora en el obispado de Palencia), entre los hijos patrimoniales, con tal de que dichos hijos patrimoniales en quienes se hubiesen provisto dichos beneficios, tengan obligacion de presentar dentro de año y medio, desde el dia de hecha en ellos la provision, ante los jueces de apelaciones de dicha provincia, ó del gobernador que alli existiere, por ratificacion de dichas Católicas majestades, ó de sus sucesores que fueren en los reinos de España, la colacion y provision que les haya sido en la forma antedicha: de otro modo, los enunciados beneficiados por esta omision ténganse por vacantes, y los referidos reyes ó sus sucesores puedan presentar para estos beneficios á otras personas, calificadas segun la forma dicha".

A resaltar de este párrafo es la mención que hace la norma a la posibilidad que en el futuro puedan proveerse beneficios del tipo que contempla no sólo a descendientes de los habitantes que de España se trasladaron a América, es decir, a criollos sino también a indios. Es llamativa la mención. En otros Decretos de erección de diócesis a pesar de la similitud que existe entre ellos indicando a todos luces un fuente común a la que siguen excluyen la admisión a estos beneficios de indios. Así, por ejemplo, el de Tucumán del año 1578 que no admite a "los hijos oriundos de dichas islas anteriores a la llegada de los cristianos a esa provincia [Tucumán], hasta que otra cosa sea dispuesta en este asunto por el mencionado nuestro católico rey Felipe o quienes le sucedieren en el tiempo [...]"49.

En el ámbito del III Concilio Provincial de México este apartado del Decreto de erección no puede pasar desapercibido sobre todo por lo resuelto en esta Asamblea al tratar de la ordenación de indios. En el Decreto conciliar finalmente

\footnotetext{
${ }^{48}$ Ibíd., $\$$ XXIV.

${ }^{49}$ Decreto de ejecución de la erección del Obispado del Tucumán, cit. (n. 30), n. 32.
} 
aprobado se dispone que los indios pueden ser admitidos a las órdenes sagradas luego de un cuidado examen ${ }^{50}$, sin embargo, esta no era la intención de los $\mathrm{Pa}$ dres conciliares. En las actas en español del Concilio, siguiendo básicamente al I Concilio de México de $1555^{51}$, se prohibía formalmente a los naturales y mestizos recibir el orden sagrado. El texto disponía que no se debían ordenar "yndios ni mestizos, assi descendientes de yndios como de moros en primer grado, ni mulatos en el mismo grado" 52 . La versión latina del Concilio enviada a Roma para su aprobación contiene una norma de las mismas características que el texto castellano referido pero en el proceso de aprobación romana de los decretos mexicanos la Congregación del Concilio hizo diferentes modificaciones y correcciones a las normas originales aprobadas en Nueva España, entre estas normas, estaba la que prohibía la ordenación de amerindios. Como resultado de esta intervención de la Santa Sede resultó aprobada una disposición diferente a la que originalmente sancionaron los conciliares ya que el Decreto corregido por la Congregación del Concilio permite admitir, "cuidadosamente", a los nativos al sacerdocio. Queda clara la particularidad de este apartado del Decreto. Éste admite, no en lo inmediato, pero como posible para el futuro la ordenación de indios mientras que la voluntad de los obispos que participaron en el Concilio era excluirla generando así - de no haber sido por la intervención romana- una contradicción en la materia dado que por un lado las normas conciliares la hubieran descartado y por el otro el Decreto de erección de la Iglesia de México que, como dice su título, es el mismo para todas las iglesias lo admitía. Esta contradicción no llamó la atención de los conciliares que sancionaron el corpus canónico original del III Concilio de México. Sólo las modificaciones de la Congregación romana disolvieron la contradicción ${ }^{53}$.

El Decreto de erección en el $\$$ XXXII manda hacer el oficio divino, las misas como las horas canónicas según la costumbre de la Iglesia de Sevilla, hasta que se celebre sínodo. El III Concilio Mexicano llena esta última salvedad en el "Decreto del Libro I, Título V, SII Obsérvese por todos el Ritual mexicano, hasta que se publique el romano".

Se establece, a instancia de la Corona, que dos veces a la semana se reúna el Cabildo. Un día para tratar de los negocios ocurrentes y el otro sólo de la corrección y enmienda de las costumbres y de todo lo vinculado a la correcta celebración del culto divino y de la honestidad del clero. Fuera de estos dos día no puede

50 "De aquí es que tampoco deben ser admitidos á los órdenes sino los que cuidadosamente se elijan de entre los descendientes en primer grado de los nacidos de padre ó madre negros, ni los mestizos, así de indios como de moros" (III Concilio Provincial DE México, Libro I, título $4^{\circ} \$$ III).

${ }^{51}$ Lundberg, Magnus, El clero indígena en Hispanoamérica: De la legislación a la implementación y práctica eclesiástica, en Estudios de Historia Novohispana, 38 (México, enero-junio, 2008), p. 49.

${ }^{52}$ Carrillo Cázares, Alberto (editor), cit. (n. 1), III, p. 62.

${ }^{53}$ Normas similares a la mexicana estudiada se encuentran el Decreto de erección de la Santa Iglesia Catedral de la Imperial en De Azúa E Iturgoyen, Pedro Felipe, Sínodo de Concepción (Chile) 1744, cit. (34), p. 18; y en el Decreto de erección de la Catedral del Cuzco por el cual también se regía la Catedral de Santiago de Chile en Carrasco SAAVEdra, Bernardo - De AldaY y Aspee, Manuel, Sínodos de Santiago de Chile de 1688 y 1763, cit. (34), p. 305. 
tenerse Cabildo a no ser que las circunstancias lo exijan. Asimismo, se recuerda la competencia episcopal para la corrección y castigo como la jurisdicción que le corresponde al obispo diocesano sobre los canónigos y demás ministros de la iglesia catedral ${ }^{54}$.

Uno de los últimos apartados del Decreto de erección nos da una pista sobre la posible fuente del mismo. En efecto en el $\$$ XXXVII se señala que el obispo podrá "reducir y trasplantar libremente las costumbres, constituciones, ritos y usos legítimos y aprobados, tanto de los oficios como de las insignias y del hábito, de los aniversarios, oficios, misas y todas las otras ceremonias aprobadas de la iglesia de Sevilla, y aun de otras cualesquiera iglesia ó iglesias que sean necesarias para regir y decorar nuestra catedral'.

Finalmente, el último apartado del Decreto reserva al obispo diocesano la facultad de modificar esta norma de acuerdo a lo que considere conveniente ${ }^{55}$.

\section{Los Estatutos.}

Los Estatutos propiamente dichos, como ya se señaló, están divididos en cuatro partes. La primera de ellas comienza regulando el ingreso del Prelado electo de la metrópoli o provincia para tomar posesión de su oficio. Se contemplan las distintas formalidades que se deberán observar según que el acto jurídico se realice por sí o por medio de un apoderado ${ }^{56}$. Se incluye el texto del juramento que deberá hacer el nuevo obispo en el que se compromete, entre otras cosas, observar y hacer observar "la erección de la santa iglesia mexicana;..." como asimismo "las constituciones publicadas del Sinodo provincial Mexicano" ${ }^{57}$ el mismo juramento deberá prestar el mandatario del electo ${ }^{58}$.

A lo largo de todo el capítulo $1^{\circ}$, los Estatutos regulan las ceremonias y ritos de la toma de posesión de la sede episcopal ${ }^{59}$ y la solemnidad que se ha de tener cuando el Prelado que ha tomado posesión por procurador entre a la ciudad ${ }^{60}$.

En el capítulo $2^{\circ}$ se regula el lugar que corresponde a los capitulares. Se enumera los distintos oficios contemplados en el Decreto de erección indicando como se sentará cada uno pero sin ninguna mención a las suspensiones que se disponían en los orígenes al erigirse la Iglesia mexicana. Se hace la salvedad del derecho que corresponde al Prelado, reconocido por el Concilio de Trento, a quien le asiste la facultad "de tener el primer lugar en el coro, en las procesiones y en cualesquiera otros actos, ó tomar la silla que quisiera elegir" ${ }^{61}$.

Del capítulo $3^{\circ}$ al Capitulo IX los Estatutos contemplan y determinan las distintas funciones que corresponden a las cinco dignidades, es decir, al deán, el

\footnotetext{
${ }^{54}$ Estatutos, Erección de la Iglesia de México, la que es igual a las demás de la misma provincia, $\$$ XXXV.

${ }^{55}$ Ibíd., $\$$ XXXVIII.

${ }^{56}$ Estatutos, $1^{\text {a }}$ parte, cap. $1^{\circ} \$ \mathrm{I}$.

${ }^{57}$ Estatutos, $1^{\mathrm{a}}$ parte, cap. $1^{\circ} \$ \mathrm{II}$.

${ }^{58}$ Estatutos, $1^{\text {a }}$ parte, cap. $1^{\circ} \$$ III.

${ }^{59}$ Estatutos, $1^{\mathrm{a}}$ parte, cap. $1^{\circ} \$ \$$ III-IV.

${ }^{60}$ Estatutos, $1^{\mathrm{a}}$ parte, cap. $s 5^{\circ}-8^{\circ}$.

${ }^{61}$ Estatutos, $1^{\mathrm{a}}$ parte, cap. $2^{\circ} \$ \mathrm{IV}$.
} 
arcedeán, el chantre, el maestreescuela y el tesorero, y a los canónigos, racioneros y medio racioneros modificando, en algún caso, el Decreto de erección.

Para el deán, establece que el mismo debe ser presbítero, requisito no exigido en el Decreto de creación de la diócesis alegando como fundamento de esta modificación lo previsto en el Tridentino y que el III Mexicano pretende cumplir ${ }^{62}$. Se específica que el deán, siempre que este en la ciudad debe citar y convocar a los capitulares a Cabildo extraordinario dando razón por escrito del motivo de la convocatoria al pertiguero para que éste lo haga saber a quienes debe notificar salvo que por la delicadeza de la materia esta indicación no sea conveniente, en tal caso, bastará con indicar que el llamado se hace por "graves negocios" dejando esta valoración a la prudencia del deán ${ }^{63}$. Será él quien propondrá los temas que tratará el Cabildo. En el caso en que el deán no quiera presentar una cuestión solicitada por algunos de los capitulares o bien en el caso que decida diferirla cualquier capitular podrá proponerla pidiendo primero licencia al Cabildo. Si también a esto se opone el deán se hará lo que decida la mayor parte del Cuerpo con su voto ${ }^{64}$. Los defectos y abusos del deán deben advertirse y corregirse por los mismos capitulares contemplando su lugar y dignidad ${ }^{65}$.

El arcedeán, que deberá ser graduado o, por lo menos, bachiller en uno de ambos derechos o en teología cumplirá y ejercerá todo lo previsto en el Decreto de erección pero se recomienda al Prelado que cuando sea posible se ponga en práctica la exhortación del Concilio de Trento ${ }^{66}$ que indicaba, cuando pudiera hacerse, que los arcedianos sean maestros en teología o doctores o licenciados en derecho canónico ${ }^{67}$. El chantre debe escribir la tabla o matrícula y lo que se ha de rezar. Indicar a las dignidades y canónigos las misas que les corresponden y a los racioneros y mediosracioneros sus textos ${ }^{68}$. A él también corresponde corregir las faltas y negligencias de los capellanes y ministros que sirven en el coro. Para el supuesto en que el chantre incumpla alguna de sus obligaciones el deán debe aplicar una justa corrección, según la naturaleza de la falta, en el Cabildo o fuera de él, considerada su dignidad ${ }^{69}$. Al maestreescuela exigía el Decreto de erección como suficiente para el ejercicio de este oficio ser bachiller en artes o en uno de los dos derechos, ahora, en cambio, el Concilio exige que se cumpla con lo ordenado por el Concilio de Trento $^{70}$. Se le impone, además, la obligación que cuando lo solicite el Cabildo escriba en nombre de este las cartas y notas que entienda necesarias, las selle con el sello capitular y las archive ${ }^{71}$. Al tesorero además de cumplir lo establecido en la Erección y en la normativa pertinente se le exige llevar el inventario de los bienes de la iglesia. Deberá, asimismo, hacer dar,

\footnotetext{
${ }^{62}$ Estatutos, $1^{\mathrm{a}}$ parte, cap. $3^{\circ} \$ \mathrm{I}$.

${ }^{63}$ Estatutos, $1^{\mathrm{a}}$ parte, cap. $4^{\circ} \$ \mathrm{II}$.

${ }^{64}$ Estatutos, $1^{\mathrm{a}}$ parte, cap. $3^{\circ} \$$ III.

${ }^{65}$ Estatutos, $1^{\mathrm{a}}$ parte, cap. $3^{\circ} \$ \mathrm{~V}$.

${ }^{66}$ Estatutos, $1^{\mathrm{a}}$ parte, cap. $4^{\circ} \$ \mathrm{I}$.

${ }^{67}$ Concilio de Trento, Sesión XXIV, cap. XII de Reforma.

${ }^{68}$ Estatutos, $1^{\mathrm{a}}$ parte, cap. $5^{\circ} \$ \mathrm{I}$.

${ }^{69}$ Estatutos, $1^{\mathrm{a}}$ parte, cap. $5^{\circ} \$$ II.

${ }^{70}$ Concilio de Trento, Sesión XXIII, Capitulo XVIII de Reforma.

${ }^{71}$ Estatutos, $1^{\text {a }}$ parte, cap. $6^{\circ} \$ \mathrm{I}$.
} 
a satisfacción del obispo y el Cabildo, la caución conveniente a los sacristanes por las cosas que estos reciban ${ }^{72}$. A los canónigos de la provincia eclesiástica además de las cualidades previstas en la Erección se exige que para ellos tenga en cuenta el Prelado lo dispuesto por el Tridentino ${ }^{73}$ en el sentido que en donde se pueda la mitad de ellos al menos sean doctores, maestros o licenciados en teología o en derecho canónico. Los canónigos dirán las Misas conventuales, excepto las que correspondan a las dignidades, según los libros litúrgicos ordenados por el Concilio de Trento. Se manda, también, observar el ceremonial ordenado por Concilio provincial ${ }^{74}$. Finalmente, para los racioneros y medio racioneros indica atenerse al Decreto de erección. Para los votos que estos deban emitir en cualquier acto o congregación capitular además de la Erección deberán observar las letras ejecutorias expedidas en juicio contradictorio ${ }^{75}$. Las prebendas por distribuciones diarias de los sujetos enumerados se rigen por el mismo Decreto de erección ${ }^{76}$. Si bien, refiriéndose a la cuestión de la división y distribución de los réditos pero extendiéndolo a todas las cuestiones que puedan suscitarse, el Concilio provincial establece aquí un principio general ordenando que el Decreto de erección es la ley fundamental y primaria a tener en cuenta "por la que se rijan y gobiernen, sin exceso ni falta alguna, todas y cada una de las iglesias catedrales de este arzobispado y provincia"77.

Luego de tratar estas cuestiones, pasa detallar como se ha de proceder en la toma de posesión de los prebendados ${ }^{78}$, la necesaria instrucción de los prebendados de reciente posesión en lo relativo al culto ${ }^{79}$, normas relativas a las capas corales ${ }^{80} y$ otras referentes al respeto y obediencia debidas a quien presida los oficios divinos indicando sus funciones ${ }^{81}$. Concluye esta parte tratando el oficio de maestro de capilla y el de los cantores ${ }^{82}$ previendo que si estos no entran al debido tiempo a la iglesia "sean multados moderadamente, atendiendo su poco salario" 83.

La $2^{\text {a }}$ parte de los Estatutos pasa a tratar del Cabildo. Luego de reiterar la disposición del Decreto de erección en cuanto al deber del Cabildo de reunirse dos veces por semana con las formalidades del caso $^{84}$ se concentra en regular el procedimiento de la votación. Así se señala, primero, que además de ser oído con cuidado el tema sobre el que se tiene que decidir si éste fuera complejo, sin clamores, se debe tener una discusión razonada y si se viera que es necesaria una "meditada consulta" se ha de postergar para otro día mediando consentimiento

\footnotetext{
${ }^{72}$ Estatutos, cit. (n. 2) , $1^{\mathrm{a}}$ parte, cap. $7^{\circ} \$ \mathrm{I}$.

${ }^{73}$ Concilio de Trento, Sesión XXIV, cap. $12^{\circ}$ de Reforma.

${ }^{74}$ Estatutos, cit. (n. 2) ,1 $1^{\text {a }}$ parte, cap. $8^{\circ} \$$ I.

${ }^{75}$ Estatutos, $1^{\text {a }}$ parte, cap. $9^{\circ} \$ \mathrm{I}$.

${ }^{76}$ Estatutos, $1^{\mathrm{a}}$ parte, cap. $9^{\circ} \$ \mathrm{II}$.

${ }^{77}$ Estatutos, $1^{\mathrm{a}}$ parte, cap. $10^{\circ}$.

${ }^{78}$ Estatutos, $1^{\mathrm{a}}$ parte, cap. $11^{\circ}$.

${ }^{79}$ Estatutos, $1^{\mathrm{a}}$ parte, cap. $12^{\circ}$.

${ }^{80}$ Estatutos, $1^{\mathrm{a}}$ parte, cap. $14^{\circ}$.

${ }^{81}$ Estatutos, $1^{\mathrm{a}}$ parte, cap. $15^{\circ}$.

${ }^{82}$ Estatutos, $1^{\mathrm{a}}$ parte, cap. $18^{\circ}$.

${ }^{83}$ Estatutos, $1^{\mathrm{a}}$ parte, cap. $18^{\circ} \$ \mathrm{IV}$.

${ }^{84}$ Estatutos, $2^{\mathrm{a}}$ parte, cap. $1^{\circ} \$ \$$ I-IV.
} 
de la mayor parte del Cabildo. Si no fuera necesario el expediente anterior el presidente debe dar su voto en primer lugar y lo hará de forma breve y razonada como, libremente y siguiendo el orden de antigüedad, todos los demás miembros del Cabildo. Si alguno interrumpe el voto de uno de sus pares debe ser castigado con pena pecuniaria ${ }^{85}$. Emitidos los votos el presidente los resumirá y recogerá y se tendrá por acordado lo que resulte de la mayoría de ellos de lo cual se levantará acta por el secretario del Cabildo. De existir oposición por alguien que considera gravosa la deliberación, el mismo presidente debe mandar que se haga constar tal protesta en las actas y que se dé copia de esta al que realizó la protesta para que si así lo entiende, recurra al juez competente. Los Estatutos, en este punto, aclaran que las cosas vinculadas a la justicia se deben resolver según ella, no por votos del Cabildo, sino por sentencia de sus letrados pudiéndose consultar peritos en derecho libres de sospecha y que en la medida de lo posible no sean capitulares. Se reconoce que en actos capitulares de esa naturaleza se originan en algunas oportunidades discordias, enemistades y altercados se recomienda la prudencia y cuidado en el uso de la palabra de lo contrario se debe recurrir a penas económicas u otras más graves a determinar por la mayoría del Cabildo. Esta pena debe ejecutarse "pospuesta absolutamente toda apelación" para atender a los daños que podrían sobrevenir y mantener las paz y concordia exigida a personas eclesiásticas agregando que como las culpas de este tipo pueden no llegar a conocimiento del obispo o su vicario se garantiza de este modo se corrijan con algún castigo ${ }^{86}$.

El secreto sobre lo deliberado puede obligar a los capitulares cuando esto se acuerde por mayoría de votos imponiéndose bajo juramento; para el que rehusé darlo se prevé una pena pecuniaria o si se estima mejor se le puede privar del derecho de voto haciéndolo salir de la sala ${ }^{87}$. Al legislar sobre los asuntos que tratará el Cabildo se contempla la incompatibilidad del capitular cuyo interés este involucrado, o el de su hermano o pariente o de quien manifieste este agraviado por él. En tal caso, este capitular no debe asistir al Cabildo mientras se trata esta cuestión ${ }^{88}$.

Si se encuentra en la iglesia, corresponde al deán convocar al Cabildo y en caso de ausencia le corresponde a la dignidad o canónigo más antiguo. Estando fuera de la iglesia corresponde al deán si está en la ciudad pero ausente de esta corresponde a la dignidad o canónigo más antiguo.

Si el asunto a tratar no pudiera esperar hasta la fecha fijada para el Cabildo el deán o estando ausente, el presidente a requerimiento de algunos capitulares no quiere convocar al Cabildo, dos o tres capitulares han de intimar al Cuerpo para que la cuestión no se pierda o se perjudique pero fuera de este caso, ninguno, bajo apercibimiento de pena grave podrá convocar a los capitulares ${ }^{89}$.

Los documentos de crédito como los mandatos, obligaciones y provisiones capitulares serán suscriptos por cuatro capitulares que se nombrarán cada mes. A

\footnotetext{
${ }^{85}$ Estatutos, $2^{\mathrm{a}}$ parte, cap. $1^{\circ} \S \mathrm{V}$.

${ }^{86}$ Estatutos, $2^{\mathrm{a}}$ parte, cap. $1^{\circ} \$ \mathrm{VI}$.

${ }^{87}$ Estatutos, $2^{\mathrm{a}}$ parte, cap. $1^{\circ} \$ \mathrm{X}$.

${ }^{88}$ Estatutos, $2^{\mathrm{a}}$ parte, cap. $1^{\circ} \$ \mathrm{XI}$.

${ }^{89}$ Estatutos, $2^{\text {a }}$ parte, cap. $1^{\circ} \$$ XII.
} 
su vez, anualmente, dos capitulares capacitados para el efecto serán nombrados contadores quienes junto con el secretario del Cabildo y el contador de la mesa capitular harán las cuentas de las distribuciones pertinentes ${ }^{90}$. Asimismo, incumbe al Cabildo nombrar, con aprobación del obispo, un capitular que se ocupe de las cosas materiales de la iglesia ${ }^{91}$. El presente capítulo concluye imponiendo al deán la obligación de ejecutar todas la disposiciones enunciadas ${ }^{92}$.

El capítulo $2^{\circ}$ trata detenidamente cuándo y como ha de convocarse los Cabildos ante diem. Se incluye en estos supuestos:

a) La asignación de salario por oficio que deba encomendarse a alguien o la condonación a otros por el Cabildo de algo que le corresponde;

b) El nombramiento de apuntador, contadores, mayordomos, maestro de ceremonias, capellanes de la iglesia, ministros, sirvientes y otros oficiales tanto de la mesa capitular como de otros asuntos cuyo nombramiento corresponda al Cabildo como también su remoción salvando el derecho del Prelado;

c) La contestación de cartas de la Curia romana o de la Corona, el nombramiento de procuradores, el obligar al Cabildo por algo, la interposición de demandas o continuar los litigios ya iniciados;

d) Dar posesión a un capitular que se deba admitir de nuevo;

e) La aceptación de legados a favor del Cabildo;

f) El envío de nuncios, tanto de los beneficiados como de otros no beneficiados;

g) Determinados actos jurídicos sobre inmuebles de la iglesia o de la mesa capitular;

h) Adoptar decisiones referentes al estado de la iglesia y,

i) Revocar o anular las cuestiones deliberadas y definidas por el Cabildo ${ }^{93}$.

Además de los Cabildos ordinarios que han de tenerse cada semana, en todas las Iglesias de la provincia, se tendrá un Cabildo general extraordinario cada dos meses para que allí se trate tanto del estado de los pleitos y asuntos pendientes como de las diligencias hechas u omitidas, de la completa o incompleta cobranza de los diezmos, si lo hubiera de la negligencia de los mayordomos y de la adopción de las medidas necesarias para la decencia del culto divino y de la celebración de los oficios ${ }^{94}$.

Los negocios de gracia, es decir, aquellos que consisten en la mera voluntad del que hace tal gracia, y que ninguna acción jurídica dan al actor si hay acuerdo de la mayor parte del Cabildo se definirán secretamente, en cambio, los llamados negocios de justicia en donde al que pide se da derecho y acción para juicio se definirán por sentencia del Cabildo tanto por votos secretos como públicos de manera que lo definido por el Cabildo si están presentes los requisitos pertinentes se ordene ejecutar ${ }^{95}$. Un asunto de gracia negado por el Cabildo y publicado el

\footnotetext{
${ }^{90}$ Estatutos, $2^{\mathrm{a}}$ parte, cap. $1^{\circ} \$ \mathrm{XIV}$.

${ }^{91}$ Estatutos, $2^{\mathrm{a}}$ parte, cap. $1^{\circ} \$$ XVII.

${ }^{92}$ Estatutos, $2^{\mathrm{a}}$ parte, cap. $1^{\circ} \$ \mathrm{XIX}$.

${ }^{93}$ Estatutos, $2^{\mathrm{a}}$ parte, cap. $2^{\circ} \$ \mathrm{I}$.

${ }^{94}$ Estatutos, $2^{\mathrm{a}}$ parte, cap. $4^{\circ} \$ \mathrm{I}$.

${ }^{95}$ Estatutos, $2^{\text {a }}$ parte, cap. $5^{\circ} \$ I$.
} 
correspondiente decreto de ninguna manera se puede volver a votar ${ }^{96}$. Se contempla en los Estatutos el supuesto que hecha la convocatoria ante diem pueda ocurrir que algún capitular, por justa causa, no haya asistido al Cabildo en donde se concedió una gracia y éste a su vez entienda que aquella no correspondía ser otorgada. En este supuesto, el capitular que ausente en el Cabildo estuviera en la ciudad puede en el plazo de tres días, tanto ante el Cabildo como ante el secretario del mismo contradecir dicha gracia de forma que en el Cabildo próximo ha de hacerlo expresamente. En el caso que el capitular ausente no hubiera estado en la ciudad al tiempo de la convocatoria puede efectuar su oposición en el término de ocho días. Hecha la protesta se suspende la gracia hasta que se proceda a una nueva votación con la participación del prebendado ausente ${ }^{97}$. Por una razón elemental de seguridad jurídica se establece que una vez deliberada en Cabildo una cuestión, sea de gracia o de justicia, no puede tratarse nuevamente sino por justa y urgente causa sobreviniente. En este caso, todos los capitulares que habían intervenido en el negocio deben participar nuevamente de la consulta y si alguno estuviera ausente se establecerá un plazo prudencial para su comparendo pero en el supuesto de peligro en la demora se procederá de acuerdo a lo que se decida por mayoría de votos del Cabildo ${ }^{98}$.

Esta parte concluye tratando del oficio y deberes del secretario del Cabildo" del sello del mismo Cabildo y de un libro especial que ha de llevarse para registrar las comisiones, encargos y diputaciones hechas por el Cabildo ${ }^{100}$.

La $3^{\text {a }}$ parte de los Estatutos regula cuestiones de orden económico. Contempla que el Cabildo nombre dos prebendados, una dignidad y un canónigo, $\mathrm{u}$ otros dos capitulares aptos quienes con la persona competente para los negocios y experimentado en diligenciar los réditos que hubiera nombrado el obispo deberán autorizar cada año las rentas decimales admitiendo las propuestas en los remates, decidan sobre los alquileres de los réditos y acepten cauciones ${ }^{101}$. El Cabildo, asimismo, tiene la obligación de nombrar algunas personas que cada año visiten las propiedades inmuebles de la iglesia y expongan a aquel el estado de los mismos ${ }^{102}$.

Para ocupar el oficio de mayordomo se exige, además de las necesarias virtudes religiosas y morales, una fianza suficiente que deberán dar antes de ser admitidos en consideración a los bienes que se les entreguen. Juntamente con sus fiadores se obligarán con promesa de hacer rendición de cuentas de aquello que se les ha confiado $^{103}$. El mayordomo de la fábrica debe dar al Cabildo, cuando este se lo

\footnotetext{
${ }^{96}$ Estatutos, $2^{\text {a }}$ parte, cap. $5^{\circ} \$$ II.

${ }^{97}$ Estatutos, $2^{\mathrm{a}}$ parte, cap. $6^{\circ} \$ \mathrm{I}$.

${ }^{98}$ Estatutos, $2^{\text {a }}$ parte, cap. $6^{\circ} \$ \mathrm{I}$.

${ }^{99}$ Estatutos, 2a parte, cap. 10.

${ }^{100}$ Estatutos, 2a parte, cap. $11^{\circ}$.

${ }^{101}$ Estatutos, $3^{\mathrm{a}}$ parte, cap. $1^{\circ} \$ \mathrm{I}$.

${ }^{102}$ Estatutos, $3^{\mathrm{a}}$ parte, cap. $1^{\circ} \$$ II.

${ }^{103}$ Estatutos, $3^{\text {a }}$ parte, cap. $2^{\circ} \$ \mathrm{I}$.
} 
requiera, la razón suficiente de los bienes que se estén por cobrar y de los cobrados como también de los gastos ${ }^{104}$.

El Decreto de erección de la Iglesia de México no estableció un tiempo de recles ${ }^{105}$, es decir de descanso, para los capitulares de la iglesia catedral que fuera de las distribuciones cotidianas no tienen otros frutos. Por su parte el Concilio de Trento prohíbe a los prebendados ausentarse más de tres meses por año salvo legislación particular en contrario que establezca un tiempo más largo ${ }^{106}$. Por su lado, los Estatutos conceden a los prebendados de todas las iglesias catedrales de la provincia un descanso de setenta días por año facultando al obispo del lugar a resolver las controversias que surjan por esta disposición ${ }^{107}$. Sin embargo, de este derecho no podrá hacerse uso en determinados días dispuestos por los mismos Estatutos $^{108}$. El prebendado, mientras hace uso de su derecho a recle, solo percibirá el montón o gruesa de su prebenda y no de otros emolumentos para cuya asignación es necesario su presencia física ${ }^{109}$.

La $4^{\text {a }}$ parte de los Estatutos contienen supuestos que regulan la enfermedad de los capitulares, de la administración de los sacramentos a éstos, del fallecimiento del Prelado y, finalmente, algunas disposiciones sobre injurias.

Se establece que en caso de enfermedad que afectaré a algún prebendado éste no tiene la obligación de asistir al coro gozando de todos los derechos que le corresponden lo mismo que si asistiera a los oficios divinos ${ }^{110}$. El mismo derecho se le reconoce a los capellanes y acólitos ${ }^{111}$.

En el caso que algún prebendado que haya tomado sus recles se encuentre fuera de la ciudad y allí contraiga una enfermedad debidamente certificada gozará del derecho reconocido a los enfermos no computándosele entre los días de recles los que estuviere enfermo. Una vez recobrada la salud volverán a correr sus días de recles ${ }^{112}$. En el supuesto que, eventualmente, algún capitular desee gozar del beneficio de los enfermos fuera de la ciudad se deberá notificar al Cabildo para que su ausencia sea manifestada a todos. No se concederá este permiso a quien pretenda morar fuera de la diócesis salvo que juré que dicha petición se funda en la prescripción de dos médicos que a su vez juren que le conviene baño saludable o temperamento de región caliente o fría ${ }^{113}$.

Enfermo de gravedad un capitular el Cuerpo nombrará dos beneficiados para que lo asistan en lo espiritual y corporal cuidando que reciba los sacramentos y

${ }^{104}$ Estatutos, $3^{\text {a }}$ parte, cap. $3^{\circ} \$ \mathrm{I}$.

${ }^{105}$ Entre los manuscritos del III Concilio Provincial Mexicano se encuentra todo un proceso presentado ante el Concilio vinculado a la cuestión. Véase Carrillo Cázares, Alberto (editor), cit. (n. 1), I, pp. 789-799.

${ }^{106}$ Concilio de Trento, sesión XXIV, cap. $12^{\circ}$ de Reforma.

${ }^{107}$ Estatutos, $3^{\mathrm{a}}$ parte, cap. $7^{\circ} \mathrm{I} \$ \mathrm{I}$.

${ }^{108}$ Estatutos, $3^{\mathrm{a}}$ parte, cap. $7^{\circ} \$ \mathrm{II}$.

${ }^{109}$ Estatutos, $3^{\mathrm{a}}$ parte, cap. $8^{\circ} \mathrm{I} \$ \mathrm{I}$.

${ }^{110}$ Estatutos, $4^{\mathrm{a}}$ parte, cap. $1^{\circ} \$ \mathrm{I}$.

${ }^{111}$ Estatutos, $3^{\mathrm{a}}$ parte, cap. $1^{\circ} \$$ III.

${ }^{112}$ Estatutos, $3^{\mathrm{a}}$ parte, cap. $2^{\circ} \$ \mathrm{I}$.

${ }^{113}$ Estatutos, $3^{\mathrm{a}}$ parte, cap. $2^{\circ} \$$ II. 
haga testamento ${ }^{114}$. Si el que enferma de gravedad es el Prelado le serán administrados los sacramentos por el presidente del Cabildo el cual será acompañado por todos los prebendados, párrocos, capellanes y ministros de la iglesia y otros sacerdotes que puedan congregarse. Al prebendado que se ausentase se lo penará con la pérdida de los emolumentos que le corresponderían en un mes que serán distribuidos entre aquellos que hubieran asistido ${ }^{115}$. Se regula también el toque de campanas al morir el Prelado ${ }^{116} \mathrm{o}$ algún capitular ${ }^{117}$ como también sobre el modo de sepultar al obispo ${ }^{118}$, a los prebendados ${ }^{119}$ y otros ministros difuntos ${ }^{120}$.

Con relación a las injurias de palabra o físicas que los prebendados se inflijan entre sí los Estatutos mandan que el presidente los multe y los reconcilie. En caso de contumacia de alguno deberá ser amonestado por el obispo ${ }^{121}$. Sin perjuicio del derecho que corresponda al damnificado de iniciar una acción judicial se recomienda evitar el escándalo con el perdón de la ofensa recibida ${ }^{122}$.

La $4{ }^{\mathrm{a}}$ parte de los Estatutos concluyen con el texto de aprobación de los mismos fechado en México el 17 de octubre de 1585 a lo que sigue la correspondiente aprobación romana del día 27 de octubre de 1589.

\section{Orden que debe observarse en el coro.}

Los mismos Estatutos ordenan que tanto como aquellos debe observarse el Ceremonial inserto a los mismos, es decir, la normativa titulada Orden que debe observarse en el coro prescripto por el Ilmo. Sr. D. Fr. Alonso de Montúfar. Como en él se indica este Orden tiene por fin velar por la debida celebración de los divinos oficios. Las reglas ha observar se refieren al silencio que se ha de respetar en el coro $^{123}$, de la autoridad del presidente ${ }^{124}$ finalizando con una detallada y abundante normativa litúrgica y disciplinaria con las penas correspondientes en caso de trasgresión ${ }^{125}$.

Como queda dicho, se tratan de normas cultuales que rigen los distintos actos que han de celebrarse en el coro y en la vida litúrgica de las catedrales del arzobispado.

\section{LAS CONSUETAS COMO FUENTE DEL DERECHO CANÓNICO INDIANO}

El estudio y consideración de los Estatutos de la Santa Iglesia de México conduce,

${ }^{114}$ Estatutos, $3^{\text {a }}$ parte, cap. $3^{\circ} \$ \mathrm{I}$.

${ }^{115}$ Estatutos, $3^{\mathrm{a}}$ parte, cap. $4^{\circ} \$ \mathrm{I}$.

${ }^{116}$ Estatutos, $3^{\mathrm{a}}$ parte, cap. $6^{\circ} \$ \mathrm{I}$.

${ }^{117}$ Estatutos, $3^{\mathrm{a}}$ parte, cap. $6^{\circ} \$ \mathrm{II}$.

${ }^{118}$ Estatutos, $3^{\mathrm{a}}$ parte, cap. $7^{\circ}$.

${ }^{119}$ Estatutos, $3^{\mathrm{a}}$ parte, cap. $7^{\circ} \mathrm{I} \$ \mathrm{I}$.

${ }^{120}$ Estatutos, $3^{\text {a }}$ parte, cap. $7^{\circ} \mathrm{I} \$ \mathrm{II}$.

${ }^{121}$ Estatutos, $3^{\mathrm{a}}$ parte, cap. $10^{\circ} \$ \mathrm{I}$.

${ }^{122}$ Estatutos, $3^{\mathrm{a}}$ parte, cap. $10^{\circ} \$ \mathrm{II}$.

${ }^{123}$ Estatutos, Orden que debe observarse en el coro prescripto por el Ilmo. Sr. D. Fr. Alonso de Montúfar, I - III.

${ }^{124}$ Ibíd., IV.

${ }^{125}$ Ibíd., V-XLII. 
necesariamente, a la reflexión sobre las fuentes del Derecho canónico indiano y, en particular, a la indagación sobre la envergadura canónica que las consuetas de las catedrales tienen en el concierto de los actos productores de este Derecho.

Es importante recordar que cuando se habla de Derecho canónico indiano se esta hablado de un derecho canónico particular por oposición a un derecho canónico universal ${ }^{126}$. El Derecho canónico indiano presenta como característica distintiva esta particularidad jurídica. En la evangelización de América la Iglesia se encontró con retos que nunca antes había enfrentado y debió buscar las soluciones canónicas que exigía la nueva realidad dando lugar a un derecho acorde a las nuevas experiencias misionales ${ }^{127}$. La autoridad eclesiástica local será el órgano principal, aunque no exclusivo, en la producción de este Derecho canónico particular ${ }^{128}$.

Por fuentes del Derecho canónico indiano ${ }^{129}$ han de entenderse, como queda dicho, por un lado, aquellas productoras de normas elaboradas en la misma América que constituyen el plexo normativo cuantitativamente más importante y, también, más interesante porque son estas las que al aplicar las normas canónicas universales a la realidad local configuran la fisonomía propia de este Derecho dándole un especificidad única sin perjuicio de reconocer, al mismo tiempo, las existencia de fuentes productoras de este Derecho generadas por Autoridad Suprema de la Iglesia.

Sin entrar a considerar las fuentes del Derecho canónico indiano propias de la Sede Apostólica, las fuentes locales pueden clasificarse, como colegiales, es decir, aquellas producidas por las asambleas jerárquicas ${ }^{130}$ como los concilios provinciales y los sínodos diocesanos celebrados en el territorio americano. Otra categoría serán las normas producidas en ejercicio de la potestad episcopal de gobierno donde se podría incluir los autos episcopales como los producidos en las visitas canónicas, los aranceles, como principio general las reglas consuetas, los ordos litúrgicos, los decretos de indulgencias, etc.

Las restantes categorías de fuentes a considerar serán la jurisprudencia eclesiástica indiana, la costumbre, la doctrina de los autores y, por último también habría que incluir las obras teológicas, morales y canónicas como los catecismos y confesionarios, manuales para misioneros, etc.

Si bien, están aún pendiente un estudio detallado y sistemático sobre las fuentes y, en general, del estatuto científico y dogmático del Derecho canónico indiano es indudable la importancia y el interés de las reglas consuetas como fuente de este Derecho. La trascendencia jurídica de estas reglas va más allá de cuanto incumbía al Cabildo, a la iglesia catedral y al culto ya que todos los clérigos de la sede

${ }^{126}$ Dellaferrera, Nelson Carlos, Fuentes del derecho canónico indiano en los siglos XVI-XVII. Los confesionarios, en Cuadernos de historia, 14 (Córdoba, 2004), p. 50.

${ }^{127}$ Dellaferrera, Nelson Carlos, cit. (n. 126), p. 51.

${ }^{128}$ PEÑA, Roberto, Notas para un estudio del derecho canónico matrimonial indiano, en Revista Chilena de Historia del Derecho, 6 (Santiago de Chile, 1970), p. 319; Martínez de SÁnCHEZ, Ana María, Fuentes, cit. (n. 3), pp. 487-489.

${ }^{129}$ González, Fernando, Apuntes liminares de Derecho Canónico Indiano, en Anuario Argentino de Derecho Canónico, 16 (Buenos Aires, 2011), en prensa.

${ }^{130}$ García y García, Antonio, Las Asambleas Jerárquicas, en Borges, Pedro (editor), Historia de la Iglesia en Hispanoamérica y Filipinas (Madrid, BAC, 1992), pp. 175-192. 
episcopal, en el caso de México de toda la provincia eclesiástica, estaban sujetos a obligaciones que surgían de ellas las cuales también afectaban a los religiosos. Es decir, las consuetas regulaban la vida pastoral de la Iglesia en torno a la catedral ${ }^{131}$ afectando a todos los fieles de acuerdo al estado canónico de cada uno de ellos.

Las consuetas de las catedrales hispanoamericanas constituyen, como queda dicho, una fuente de sumo interés para el Derecho canónico indiano. En ellas no sólo se contienen normas de Derecho litúrgico sino también de disciplina eclesiástica ampliando notablemente su espectro de influencia y convirtiéndose de esta manera en un yacimiento aún pendiente en mucho de explorar del Derecho canónico en América española.

\section{CONCLUSIONES}

Los Estatutos del III Concilio Provincial de México presentan diferencias singulares con relación a otros cuerpos normativos similares superando a estos en muchos aspectos incluso a las Ordenanzas de santo Toribio ${ }^{132}$ por ser más puntuales en la regulación y por el volumen de normas que constituyen el cuerpo legal estudiado. Los Conciliares mexicanos no se limitaron a establecer normas litúrgicas o ajustar a su realidad determinados aspectos de la disciplina eclesiástica y de la cura pastoral de sus diócesis sino que, además, han aportado novedades que estas reglas no suelen contener. El detenimiento en la regulación del funcionamiento del Cabildo es una de ellas, cabe asimismo mencionar la regulación pormenorizada del oficio de administrador de réditos decimales y otros oficios vinculados a la cuestión económica, como también el detalle en la legislación referente al recle y lo que se establece en la $4^{\mathrm{a}}$ parte de los Estatutos sobre los diversos supuestos de imposibilidad física que puedan afectar al obispo o a los capitulares como el modo de proceder al fallecer estos.

Se ha dicho más arriba que, por lo general, el tipo de norma analizada $4^{\mathrm{a}}$ parte surgía luego de la celebración de un sínodo, como parte de este o, también, como un acto legislativo del obispo, de ordinario, ayudado por colaboradores en la redacción de la regla. Los Estatutos de la Iglesia de México tienen como particularidad exclusiva ser fruto de todo un Concilio, el de 1585, y es la única regla consueta que goza de la doble aprobación pontificia y real.

En resumen: Son conocidas y publicadas la mayoría de las reglas consuetas del período temporal que abarca el Derecho canónico indiano aunque los trabajos de investigación específicos sobre las mismas son pocos basta ver el elenco de

${ }^{131}$ Oviedo Cavada, Carlos, cit. (n. 3), p. 133. En el mismo sentido: A. M. Martínez de SÁNCHEZ, Las consuetas de las catedrales de Santiago del Estero y Córdoba, cit. (n. 3), p. 68.

${ }^{132}$ Es un muy probable que santo Toribio de Mogrovejo haya seguido a los Estatutos mexicanos en varios puntos de su Ordenanza o, al menos, en ambas legislaciones ha de reconocerse un antecedente en común. Este paralelo puede verse entre otros al regularse el funcionamiento del Cabildo eclesiástico. Se produce en este caso un proceso inverso a la relación que existe entre los Concilios limenses y el III Mexicano. Mientras que aquellos han sido asumidos como fuente por la Asamblea novohispana de 1585, al establecer su regla consueta el arzobispado de Lima recurrió a la Iglesia del norte de América como guía de sus disposiciones. 
bibliografía que se ha señalado al tratar de las consuetas en general. El canonista que desee profundizar en la historia del Derecho canónico en Indias tiene delante de sí todo un filón de investigación con el que contribuir a la ciencia del Derecho de la Iglesia. La aplicación y observancia de estas reglas se ha de confrontar con el estudio de las actas capitulares de los respectivos Cabildos eclesiásticos, sobre todo, teniendo en cuenta las largas y no siempre pacíficas vacancias episcopales que se produjeron en América circunstancia esta última que incrementa el valor jurídico de estas disposiciones en particular de aquellas consuetas que como las de México y Perú regulan lo relativo al funcionamiento y atribuciones de los Cabildos.

\section{BiBLIOGRAFÍA}

Arriaga, Benito Notas, en Galván Rivera, Mariano (editor), Concilio III Provincial Mexicano (México, Eugenio Mailleferte y Compañía, 1859).

Barrientos Grandon, Javier, Historia del Derecho indiano (Roma, Il Cigno Galileo Galilei, 2000).

Burrus, Ernest, Salazar's report to the Third Mexican Council, en The Americas, 17 (Washington, 1960).

Burrus, Ernest, The Autor of the Mexican Council's Catechisms, en The Americas, 15 (Washington, 1958).

Carrasco Saavedra, Bernardo-De Alday y Aspée, Manuel, Sinodos de Santiago de Chile de 1688 y 1763 en García y García, Antonio - Santiago-Ottero, Horacio - (editores), Sínodos Americanos (Madrid-Salamanca, Instituto "Francisco Suárez" del CSIC-Instituto de Historia de la Teología Española de la UPS, 1983), II.

CARRILlo CÁZARes, Alberto (editor), Manuscritos del concilio tercero provincial mexicano (1585). Edición, estudio introductorio, notas, versión paleográfica y traducción de textos latinos (Zamora, El Colegio de Michoacán - Universidad Pontificia de México, 2006-2010).

de Azúa e Iturgoyen, Pedro Felipe, Sínodo de Concepción (Chile) 1744 en SantiagoOtero, Horacio - García y García, Antonio (editores), Sínodos Americanos (Madrid-Salamanca, Instituto "Francisco Suárez" del CSIC-Instituto de Historia de la Teología Española de la UPS, 1984), III.

Decreto de ejecución de la erección del Obispado del Tucumán firmado por el Obispo Francisco de Vitoria en Sevilla: 18.XI. 1578, en Arancibia, José María-Dellaferrera, Nelson (editores), Los Sinodos del Antiguo Tucumán (Buenos Aires, Teología, 1979).

Dellaferrera, Nelson Carlos, Fuentes del derecho canónico indiano en los siglos XVIXVII. Los confesionarios, en Cuadernos de historia, 14 (Córdoba, 2004).

Dougnac Rodríguez, Antonio, Manual de Historia del Derecho Indiano (México, Instituto de Investigaciones Jurídicas, 1994).

Durán, Juan Guillermo, La transmisión de la fe. Misión apostólica, catequesis y catecismos en el Nuevo Mundo (siglo XVI), en Escudero Imbert, José (editor), Historia de la Evangelización de América. Trayectoria, identidad y esperanza de un continente. Actas del Simposio Internacional (Ciudad del Vaticano, Libreria Editrice Vaticana, 1992). 
Durán, Juan Guillermo, Monumenta Catechetica hispanoamericana. (Siglos XVI-XVIII), III (pro manuscrito).

Estatutos ordenados por el Santo Concilio III Provincial Mexicano en el año del Señor MDLXXXV según el mandato del Sacrosanto Concilio Tridentino, decretado en la sesión XII, cap. 24 de la Reformación, en la palabra Cetera, en GaLVÁN RIVERA, Mariano (editor), Concilio III Provincial de México (México, Eugenio Mailleferte y Compañia, 1859).

ForNes AzCoITI, Ignacio, El proceso de la aprobación romana del III Concilio de México (1585-1589), Tesis doctoral (Roma, Pontificia Universidad de la Santa Cruz, 2005).

Fuentes de archivo para el estudio del Derecho canónico indiano local, en Revista de Estudios Históricos-Jurídicos, 30 (Valparaíso, 2008).

Galindo Bustos, Jesús, Estudio del aparato de fuentes del Tercer Concilio Mexicano. Tesis doctoral (Roma, Pontificia Universidad de la Santa Cruz, 2004).

Galván Rivera, Mariano (editor), Concilio III Provincial de México (México, Eugenio Mailleferte y Compañia, 1859).

García Prieto, Zenón, Los tres primeros concilios de México, en Revista Española de Derecho Canónico, 46 (Salamanca, 1989).

García y García, Antonio, Las Asambleas Jerárquicas, en Borges, Pedro (editor), Historia de la Iglesia en Hispanoamérica y Filipinas (Madrid, BAC, 1992).

GonzÁlez, Fernando, Apuntes liminares de Derecho Canónico Indiano, en Anuario Argentino de Derecho Canónico, 16 (Buenos Aires, 2011).

Grignani, Mario, La regla consueta de santo Toribio de Mogrovejo y la primera organización de la Iglesia americana (Santiago de Chile, Ediciones Universidad Católica de Chile, 2009).

LLAGUNO, José, La personalidad jurídica del indio y el III concilio provincial mexicano (1585) (México, Porrúa, 1963).

Lopetegui, León - Zubillaga, Félix, Historia de la Iglesia en la América Española. Desde el Descubrimiento hasta comienzos del siglo XIX. México. América Central. Antillas (Madrid, BAC, 1965).

Lorenzana, Francisco, Apéndice a los Concilios mexicanos primero y segundo, publicados por Nicolás de León. Bibliografía mexicana siglo XVIII (México, Imprenta del Superior Gobierno 1907).

LundBerg, Magnus, El clero indígena en Hispanoamérica: De la legislación a la implementación y práctica eclesiástica, en Estudios de Historia Novohispana, 38 (México, enero-junio, 2008).

LundBerG, Magnus, Las Actas de los tres primeros concilios mexicanos. Historia diplomática y estudio de su itinerario, en Anuario de Historia de la Iglesia, 15 (Pamplona, 2006).

Luque AlCaide, Elisa, El memorial inédito de Jerónimo Mendieta al III Concilio provincial de México (1585) Estudio preliminar y trascripción, en Anuario de Historia de la Iglesia, 1 (Pamplona, 1992).

LUQUe AlCAIDE, Elisa, Experiencias evangelizadoras granadinas en el III Concilio Mexicano, en AA.VV El reino de Granada y el Nuevo Mundo (V Congreso internacional de Historia de América) (Granada, Diputación Provincial de Granada, 1994), I.

Martínez de SÁnChez, Ana María, Las consuetas de las catedrales de Santiago del Estero y Córdoba en los siglos XVII y XVIII, en GonZÁLEZ VALE, Luis (coordinador), Actas y Estudios del XIII Congreso del Instituto Internacional de Historia del Derecho 
Indiano (San Juan de Puerto Rico, Historiador Oficial de Puerto Rico-Asamblea Legislativa de Puerto Rico, 2003), II.

Martínez de Sánchez, Ana María, Las consuetas del obispado de Tucumán, en Revista de Estudios Históricos-Jurídicos, 28 (Valparaíso, 2006).

Martínez Ferrer, Luis, Decretos del Concilio tercero provincial mexicano (1585), edición histórico crítica y estudio preliminar (Zamora, El Colegio de Michoacán Universidad Pontificia de la Santa Cruz 2009-2010).

MarTínez Ferrer, Luis, Directorio para confesores y penitentes. La pastoral de la confesión en el Tercer Concilio Mexicano (1585) (Pamplona, Eunate, 1996).

Martínez Ferrer, Luis, El sacramento de la confesión en el Directorio para confesores y penitentes del Tercer Concilio Mexicano (1585). Tesis doctoral, en Anuario de Historia de la Iglesia, 5 (Pamplona, 1996).

Martínez Ferrer, Luis, Fuentes e historiografía del III Concilio Mexicano (1585), en Saranyana, Josep-Ignasi y otros (editores), Actas del XVI Simposio Internacional de Teología de la Universidad de Navarra (Pamplona, Eunsa 1996).

Martínez Ferrer, Luis, La penitencia en la primera evangelización de México (15231585) (México, Universidad Pontificia de México, 1998, Otras recepciones de Trento en América (1585-1628), en SARANYANa, Josep-Ignasi (editor), Teología en América Latina. Desde los orígenes a la Guerra de Sucesión (1493-1715) (Madrid, Iberoamerica, 1999), I.

Ortiz Treviño, Rigoberto, El tercer concilio provincial mexicano, o como los obispo evadieron al real patronato indiano, en Anuario Mexicano de Historia del Derecho, XV (México, 2003).

Oviedo Cavada, Carlos, Las consuetas de las catedrales de Chile, 1689 y 1744, en Revista Chilena de Historia del Derecho, 12 (Santiago de Chile, 1986).

PEÑA, Roberto, Notas para un estudio del derecho canónico matrimonial indiano, en Revista Chilena de Historia del Derecho, 6 (Santiago de Chile, 1970).

Pérez Puente, Leticia, Dos proyectos postergados. El Tercer Concilio Provincial Mexicano y la secularización parroquial, en Estudios de Historia Novohispanos, 35 (México Julio-Diciembre, 2006).

Poole, Richard, Pedro Moya de Contreras. Catholic reform and Royal Power in New Spain 1571-1591 (Berkeley - Los Angeles, University of California Press, 1987).

Saranyana, , Josep-Ignasi - Alejos-Grau, Carmen, La Primera Recepción de Trento en América (1565-1582) en Saranyana, Josep-Ignasi (editor), Teología en América Latina. Desde los origenes a la Guerra de Sucesión (1493-1715) (Madrid, Iberoamerica, 1999), I.

Saranyana, Josep-Ignasi - LuQue Alcalde, Elisa, Fuentes manuscritas inéditas del III Concilio Mexicano (1585), en Annuarium Historia Conciliorum, 22 (Paderborn, 1990).

Saranyana, Josep-Ignasi - Luque AlCalde, Elisa, Los instrumentos pastorales del III Concilio Mexicano (1585), en Scripta Theologica, 23 (Roma, 1991).

SARANYANA, Josep-Ignasi, Sobre los orígenes del cristianismo en América. Historia doctrinal de una polémica, en Anuario de Historia de la Iglesia, 1 (Pamplona, 1992).

TAu AnZó́tegui, Víctor, El poder de la costumbre. Estudios sobre el Derecho Consuetudinario en América hispana hasta la emancipación (Instituto de Investigaciones de Historia del Derecho, Buenos Aires, 2001).

TERrÁneo, Sebastián, La recepción de la tradición conciliar limense en los Decretos del III 
Concilio Provincial Mexicano. Tesis doctoral (Buenos Aires, Pontificia Universidad Católica Argentina, 2010).

Zubillaga, Félix, Tercer Concilio Mexicano, 1585: Los memoriales de Juan de la Plaza, S.J., en Archivum Historicum Societatis Jesu, 30 (Roma, 1961). 
